University of Nebraska - Lincoln

DigitalCommons@University of Nebraska - Lincoln

Reports from the Food Processing Center, University of Nebraska-Lincoln

2021

\title{
Effects of Splits Content on Dry Matter Loss Rates of Soybeans Measured Using a Static Grain Respiration Measurement System
}

Ana B. Gatsakos

University of Illinois at Urbana-Champaign, abp3@illinois.edu

Thomas B. Scatolini

University of São Paulo, thomas.scatolini@usp.br

Mary-Grace C. Danao

University of Nebraska-Lincoln, mdanao2@unl.edu

Richard S. Gates

lowa State University, rsgates@iastate.edu

Kent D. Rausch

University of Illinois at Urbana-Champaign, kdrausch@illinois.edu

Follow this and additional works at: https://digitalcommons.unl.edu/fpcreports

Part of the Food Science Commons

Gatsakos, Ana B.; Scatolini, Thomas B.; Danao, Mary-Grace C.; Gates, Richard S.; and Rausch, Kent D., "Effects of Splits Content on Dry Matter Loss Rates of Soybeans Measured Using a Static Grain Respiration Measurement System" (2021). Reports from the Food Processing Center, University of Nebraska-Lincoln. 11.

https://digitalcommons.unl.edu/fpcreports/11

This Article is brought to you for free and open access by the Food Processing Center at DigitalCommons@University of Nebraska - Lincoln. It has been accepted for inclusion in Reports from the Food Processing Center, University of Nebraska-Lincoln by an authorized administrator of DigitalCommons@University of Nebraska - Lincoln. 


\title{
EFFECTS OF SPLITS CONTENT ON DRY MATTER LOSS RATES OF SOYBEANS MEASURED USING A STATIC GRAIN RESPIRATION MEASUREMENT SYSTEM
}

\author{
Ana B. Gatsakos ${ }^{1}$, Thomas B. Scatolini' ${ }^{2}$, Mary-Grace C. Danao ${ }^{3}$, Richard S. Gates ${ }^{4}$, Kent D. Rausch ${ }^{1, *}$
}

Highlights

- Respiration rate increased with percentage of split beans.

- Splits multiplier for soybeans appears to be more sensitive than the corn damage multiplier.

- Relationship between split percentage and splits multiplier for soybeans is approximately linear.

- Value for splits multiplier for beans at $18 \%$ moisture content soybeans stored at $35^{\circ} \mathrm{C}$ is provided.

ABSTRACT. The objectives of this study were to compare effects of 0-16\% (w/w) splits content $\left(x_{s}\right)$ of soybeans stored at $35^{\circ} \mathrm{C}$ and $18 \%$ moisture content (w.b.) on dry matter loss rates (vDML), and to determine a splits multiplier $\left(M_{S}\right)$ for soybeans stored at these conditions, similar to the damage multiplier $\left(M_{D}\right)$ utilized in ASABE Standard D535 for shelled corn. Effects of percentage by weight splits $\left(x_{s}\right)$ on $M_{S}$ and safe storage time are expected to be greater than $M_{D}$ for corn because soybeans are prone to cracking and splitting, lipid oxidation, and protein degradation - all of which lead to grain dry matter and quality losses. Results indicated $v_{D M L}$ increased with increasing $x_{s}$ and mean $v_{D M L}$ for samples with $16 \%$ splits was 1.5 times greater than that for samples with $4 \%$ splits. $M_{S}$ for soybeans was linearly correlated with $x_{s}$, decreasing from 1.0 to 0.60 for $0 \%$ to $16 \%$ splits, respectively. Soybeans appeared to be more sensitive to percent by weight splits than was corn to the presence of damaged kernels. $M_{D}$ for corn only decreased from 1.0 to 0.8 when percent ( $w / w$ ) damaged kernels content increased from $30 \%$ to $40 \%$. In comparison, it should be noted that damage to soybeans was defined differently from damage to corn. This research is useful in defining $M_{S}$ for $18 \%$ moisture content soybeans stored at $35^{\circ} \mathrm{C}$ under hermetic conditions. The 
procedures outlined in this paper may be used in the future to more formally define a soybean $M_{S}$ that covers a wider range of moisture contents, storage conditions and possibly a $M_{D}$ based on other factors included in the USDA definitions of damaged soybean kernels.

Keywords. allowable storage time, grain quality, splits multiplier

\section{INTRODUCTION}

Different cereal grains and oilseeds start deteriorating from the time of harvest. During storage, two factors influence deterioration rates and, ultimately, grain dry matter and quality losses. The first factor is the presence of spoilage organisms, such as mites, molds, insects, and mycotoxins. The second factor is unfavorable storage conditions, such as high temperature, low oxygen levels, and high moisture in the grain and surrounding air (Coker, 1994). However, even in the absence of spoilage organisms and with favorable storage conditions, grain will continue to respire, albeit at rates so low that they are practically negligible, and the grain can be safely stored indefinitely. Storage of shelled corn has been studied extensively and it has been found that increases in storage temperature (T), moisture content $(w)$, or total damaged kernels $(D)$ can decrease dramatically the safe storage time $\left(t_{s}\right)$; alternatively, increases in fungal resistance from either hybrid traits or fungicide application can increase $t_{s}$.

To estimate shelled corn storage time for 0.5\% dry matter loss (DML), ASABE Standard D535 (R2019) provides an equation for $t_{\mathrm{s}}$ :

$$
t_{s}=9.583 M_{T} M_{W} M_{D} M_{H} M_{F}
$$

where $M_{T}, M_{w}, M_{D}, M_{H}$, and $M_{F}$ are temperature, moisture, damage, hybrid resistance, and fungicide

multipliers, respectively. For shelled corn, these multipliers are all equal to unity for a generic hybrid without fungicide treatment, held at $25 \%$ (w.b.) moisture content and $15.6^{\circ} \mathrm{C}$, and assuming $30 \%(\mathrm{w} / \mathrm{w}$ ) of kernels have been damaged during mechanical harvest. Effects of $w$ and $T$ on $t_{s}$ are laid out in a table 
in the standard and have been a useful guide for those who are storing corn in bins or holding corn in transport vessels. Equation 1 and $t_{s}$ values in the standard were based on several studies that measured carbon dioxide production of different hybrids of shelled corn at different $T, M, D$, and fungicide treatments to develop individual equations for these multipliers.

To attain a better understanding of the effects of temperature, moisture content, and damage on $t_{s}$, their corresponding multipliers $\left(M_{T}, M_{w}, M_{D}\right)$ were first plotted as shown in figure 1 and then applied to the following example. Suppose shelled corn at $16 \%$ moisture content is stored at $15.6^{\circ} \mathrm{C}$. Using ASABE Standard D535 (R2019), for this set of conditions, $M_{T}$ and $M_{w}$ are equal to 0.993 and 15.8, respectively. Assuming $M_{D}, M_{H}$, and $M_{F}$ are all equal to unity, this corn can be stored safely for up to 151 days from the time of harvest according to equation 1 . If storage $T$ is increased to $26.7^{\circ} \mathrm{C}, M_{T}$ changes to 0.312 and $t_{s}$ decreases to 47.3 days. If instead the $15.6^{\circ} \mathrm{C}$ corn gains moisture and reaches $20 \%, M_{w}$ decreases to 2.945 and $t_{s}$ decreases to 28.1 days. If $T$ increases from $15.6^{\circ} \mathrm{C}$ to $26.7^{\circ} \mathrm{C}$ and $w$ increases from $16 \%$ to $20 \%$ moisture content, the net effect is a decrease in $t_{s}$ to 8.8 days. 


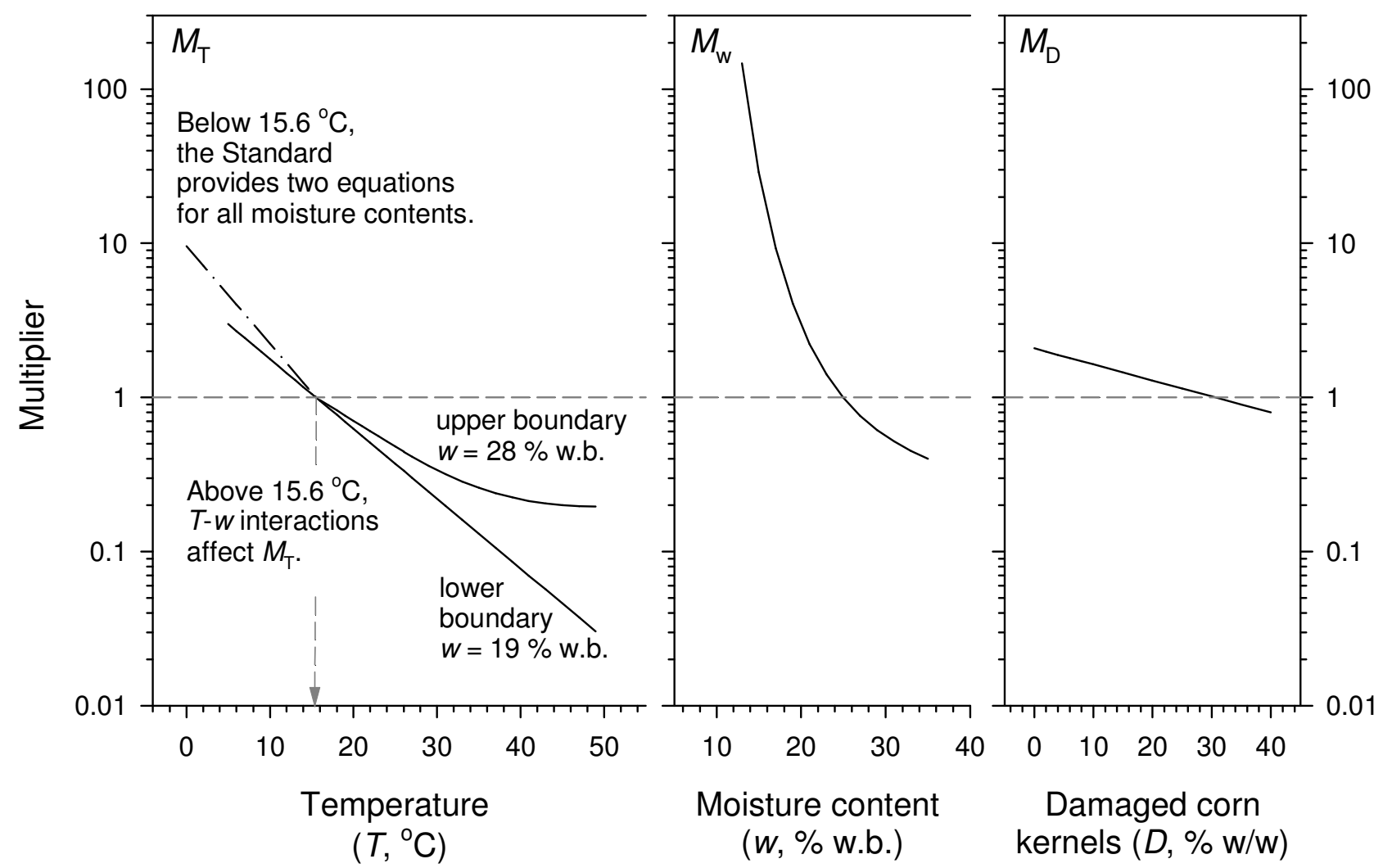

Figure 1. Multipliers (M) for temperature $\left(\mathrm{T},{ }^{\circ} \mathrm{C}\right)$, moisture (w, \% w.b.), and damage level $(\mathrm{D}, \% \mathrm{w} / \mathrm{w})$ defined in the ASABE Standard D535 (R2019) for shelled corn. At conditions $T=15.6^{\circ} \mathrm{C}, \mathrm{w}=25 \% \mathrm{w} . b$. and $\mathrm{D}=30 \% \mathrm{w} / \mathrm{w}$, MT, Mw, and MD have a value of unity.

Note that the concept of safe storage time or maximum allowable storage time is cumulative, meaning, the amount of time that the corn was stored in the first set of storage conditions must be accounted for when determining the remaining amount of time it can be stored in subsequent storage conditions. For example, if $18 \%$ moisture corn was harvested and transported at $35^{\circ} \mathrm{C}$ for 2 days, $89 \%$ equilibrium relative humidity (ERH), approximately 2 days of the 8 days maximum allowable (25\%) of its "shelf-life" or safe storage time towards $0.5 \% \mathrm{DML}$ has occurred. Then, if it is subsequently dried and stored at $16 \%$ moisture content and $26.7^{\circ} \mathrm{C}$, it has $75 \%$ of its shelf-life remaining, which is $0.75 \times 47$ days $=35$ days.

Of these three factors, the effect of damage on $t_{s}$ is not as dramatic as those of temperature and moisture content, i.e., the $M_{D}$ curve in figure 1 is not as steep as the $M_{T}$ and $M_{w}$ curves. In other parts of the world 
such as Brazil, corn harvest can begin as soon as the grain moisture content decreases to $30 \%$ moisture content, but ideal harvest conditions are typically when corn is at 20-25\% moisture content grain. Cracked or broken kernels result when the combine is poorly adjusted such that more beating, shearing, or pinching of grain occurs. During drying, stress cracks can form if drying temperature is too high, or if the grain is rapidly cooled after heating in the dryer (Fortes \& Okos, 1980; Steele, 1967). Hence, ASABE Standard D535 (R2019) assumes a $D$ of 3\% (w/w) for hand-shelled corn, 30\% (w/w) for mechanically harvested corn under typical conditions, and $40 \%$ for corn that is heavily damaged during harvest. These $D$ levels correspond to damage multiplier $\left(M_{D}\right)$ of 2.0, 1.0, and 0.8, respectively (fig. 1) meaning hand-shelled corn can be safely stored for twice as long as mechanically harvested corn under typical conditions at the same $T$ and $w$. However, a $10 \%$ increase in $D$ decreases $t_{s}$ by $20 \%$.

The type of damage to soybeans and other legumes is different from types of damage inflicted on corn. A corn kernel has an outer shell (pericarp) protecting its endosperm which does not readily separate, but a soybean seed has a moderately fragile thin seed coat that cracks, revealing two cotyledons that readily split to expose interior surfaces and embryo to fungal attack and oxidation. Therefore, it is expected that splitting of cotyledons will have a significant effect on quality loss in soybeans and other legumes. At optimum harvest moisture contents of $13 \%$ to $15 \%$ for soybeans for maximum weight and minimum field losses, soybean seeds are prone to cracking after impacting metal surfaces in the combine and as a result of impacts with other seeds and surfaces during harvest and handling (Bern et al., 1999). According to Paulsen et al. (1981), soybeans' germination decreased with increase in harvest damage even when stored at a minimum moisture content. Soybean is susceptible to hydrolysis of triglycerides and protein degradation, leading to elevated levels of free fatty acids (FFA) and decreased protein content during storage (Alencar et al., 2010; Bern et al., 1999; Kong \& Chang, 2013). Elevated levels of FFA in split soybeans have been correlated to poor oil quality (Mustakas et al., 1969) and refining losses during 
soybean oil processing (Carr, 1976). Thus, while effects of $T$ and moisture content on $t_{s}$ for corn and soybeans may be comparable, effects of damaged and percentage of split beans $\left(x_{s}\right)$ on $t_{s}$ and dry matter loss rate $\left(v_{D M L}\right)$ are expected to be significant and must be quantified. Effects of storage moisture content, temperature, and other factors on quality attributes, such as oil and protein degradation, will need to be quantified for eventual development of a mathematical model to estimate maximum allowable storage time of soybeans.

Objectives of this study were to (1) compare $v_{D M L}$ of $18 \%$ moisture content soybeans with $0 \%$ to $16 \%$ (w/w) split beans content stored at $35^{\circ} \mathrm{C}$, and (2) to use these results to determine a splits multiplier $\left(M_{S}\right)$ for soybeans stored at these conditions, similar to multipliers utilized in ASABE Standard D535 (R2019) for corn. Storage conditions chosen in this paper are typical for soybean harvest and initial storage conditions in low latitude regions. In these regions, it is difficult to harvest and store soybeans at optimum moisture; a harvest moisture of $18 \%$ is frequently encountered. For example, while harvesting soybeans in Mato Grosso, Brazil, moisture contents often range from 10.8 to $25.7 \%$, average ambient temperatures range from 19.7 to $35.1^{\circ} \mathrm{C}$ and the period of time required to transport beans to a drying facility ranges from 1 to $16 \mathrm{~h}$ (Danao et al., 2015).

\section{MATERIALS AND METHODS}

\section{Soybeans And SAmple Preparation}

Soybeans (28T33R, DuPont Pioneer, Johnston, IA, USA) were combine harvested at approximately 15\% moisture content from the Crop Sciences Research and Education Farm of the University of Illinois at Urbana-Champaign in October 2016. The soybeans were dried at ambient conditions to $12 \%$ to $13 \%$ moisture content and placed in a bin equipped with a fan at outdoor environmental temperatures, ranging from $12^{\circ} \mathrm{C}$ to $-1.6^{\circ} \mathrm{C}$. Moisture migration was prevented with cycles of aeration in the bin. On 19 January 2017, approximately $327 \mathrm{~kg}$ were removed from storage, placed in plastic containers (68 L capacity), and 
stored at $4^{\circ} \mathrm{C}$ until testing, September 2017.

A batch of split soybeans was initially prepared by retrieving $3 \mathrm{~kg}$ from cold storage and screening them with Sieve 1, a slotted sieve with $3.97 \mathrm{~mm}$ by $19 \mathrm{~mm}$ (10/64" by 3/4”) openings (Grainman, Miami, FL, USA) to remove small impurities and split beans (fig. 2). Larger impurities and damaged beans were handpicked from the remaining whole soybeans. To generate split beans for later use, the cleaned sample was passed through a custom-fabricated laboratory corn degerminator (Rausch et al., 2009; Somavat et al., 2017) and screened using Sieve 1 and also Sieve 2, a USA Standard No 8, which has circular openings with a diameter of $2.360 \mathrm{~mm}$ (Dual Manufacturing Co., Franklin Park, IL, USA). Samples were separated into $700 \mathrm{~g}$ aliquots, which were placed in sealed plastic bags prior to storing at $4{ }^{\circ} \mathrm{C}$.

Before each respiration test, four glass desiccators (10 L capacity each) were placed in an incubator (Model No 3033, Steri-Culti 200, Forma Scientific, Inc., Marietta, OH, USA) set at $35^{\circ} \mathrm{C}$ to acclimatize. A single $700 \mathrm{~g}$ aliquot of split soybeans was removed from cold storage and spread onto a tray to acclimate at room temperature (approximately $23^{\circ} \mathrm{C}$ ) for $30 \mathrm{~min}$ to $40 \mathrm{~min}$. In the same fashion, a $3 \mathrm{~kg}$ sample of whole soybeans was removed from cold storage and acclimated on a separate tray. Split and whole soybean moisture contents were estimated using a portable moisture meter (Model No SW16060, John Deere, Moline, IL, USA). These moisture measurements were used to estimate the amounts of water to be 


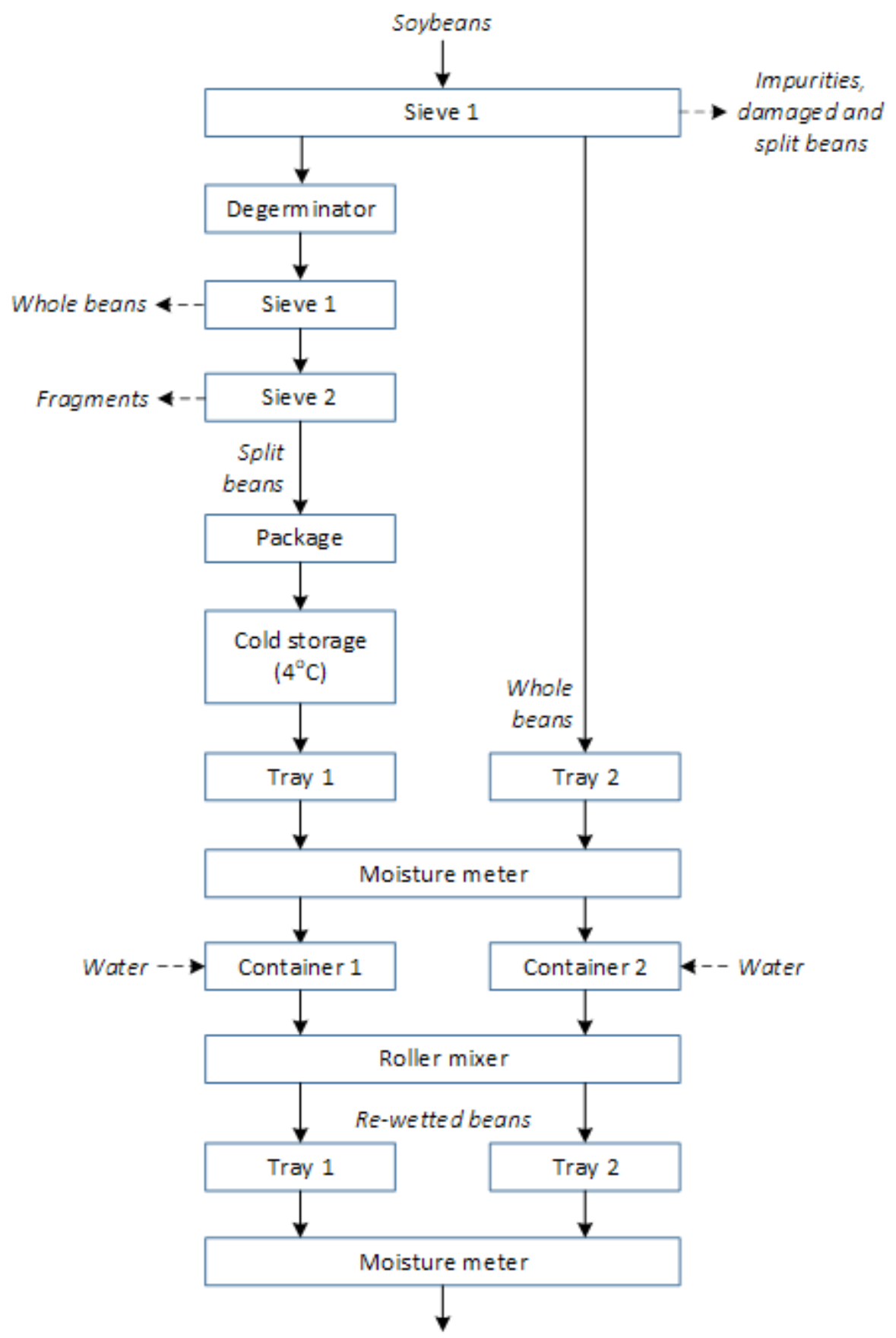

Mixed sample $(0,4,8$, and $16 \% \mathrm{w} / \mathrm{w}$ split beans content)

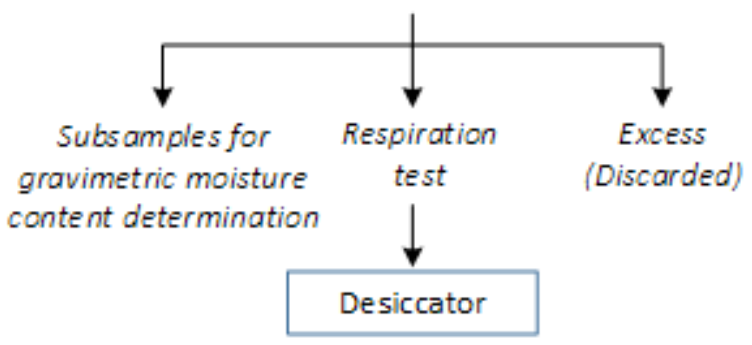

Figure 2. Soybean sample preparation. 
added to reach the desired $18 \%$ moisture content for testing. Whole and split soybeans were placed in separate containers and slowly rehydrated over a $60 \mathrm{~min}$ interval by adding the required amount of water (plus $10 \mathrm{~mL}$ of excess water) every $10 \mathrm{~min}$. Between water additions, the containers were placed on roller mixers (Model No MX-T6-S, Scilogex, Rocky Hill, CT, USA) set to $60 \mathrm{rpm}$.

After 60 min of re-wetting, the moisture content of both batches was estimated using the portable moisture meter. Then, whole and split soybeans were spread into thin layers on separate trays to facilitate the evaporation of excess moisture at room temperature for $30 \mathrm{~min}$ to $40 \mathrm{~min}$. Every $5 \mathrm{~min}$, the moisture content of both batches were estimated using the portable moisture meter. Once $18 \%$ moisture content was reached, split beans were mixed with whole soybeans to yield four levels of $x_{s}(0,4,8$, and $16 \% \mathrm{w} / \mathrm{w})$, where $0 \%(\mathrm{w} / \mathrm{w})$ splits served as a control sample. Each mixture weighed approximately $500 \mathrm{~g}$. From the remaining split beans and whole soybeans, three subsamples (30 g each) were set aside for gravimetric moisture content measurement following ASABE Standard S352.2(R2017). Each $500 \mathrm{~g}$ of mixed sample was placed in an acclimated desiccator (10 L capacity) equipped with a sensor package with a built-in datalogger (Model K33-BLG, CO2Meter, Inc., Ormond Beach, FL, USA) and sealed hermetically with vacuum grease (fig. 3). All filled desiccators were placed in the $35^{\circ} \mathrm{C}$ incubator.

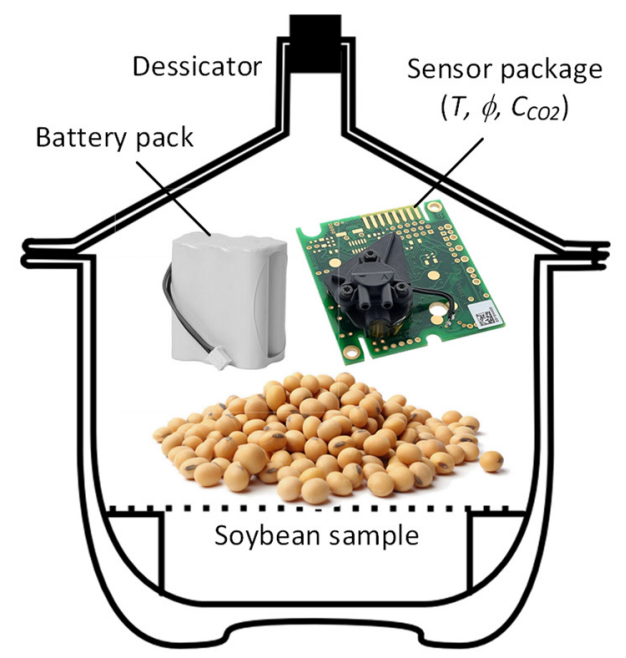

Figure 3. Components of static grain respiration measurement system (S-GRMS). 


\section{Respiration Data Collection and Analysis}

\section{Respiration tests}

Prior to a respiration test, each desiccator/sensor package was assigned to a single $x_{s}$ level and calibrated according to procedures described in Pereira Da Silva (2018) with a two-point method using $\mathrm{N}_{2}$ gas (for zero) and certified calibration gas for span. The sensor packages' built-in data loggers were set to record $T\left({ }^{\circ} \mathrm{C}\right)$, relative humidity $(\phi, \% \mathrm{RH})$, and carbon dioxide concentration $\left(\mathrm{C}_{\mathrm{CO}_{2}}, \%\right)$ inside each desiccator every 10 min for 10 days.

The experiment was a completely randomized design with replication. Each set of respiration tests consisted of one each of the four $x_{s}$ levels, randomly assigned to one of the four desiccators; the set of respiration tests was replicated five times with new soybean samples. At the end of each respiration test, three subsamples (30 g each) previously set aside from each desiccator were used to determine moisture content according to ASABE Standard S352.2 (R2017). Each $30 \mathrm{~g}$ sample was transferred to a metal container and heated in a forced convection oven at $103^{\circ} \mathrm{C}$ for $72 \mathrm{~h}$. Moisture content was determined from the difference in sample weight before and after oven drying. Initial and final moisture content measurements for each test were within $\pm 1 \%$ of the equilibrium moisture content, corresponding to measured relative humidity of $88 \% \mathrm{RH}( \pm 5 \%)$ and temperature of $35^{\circ} \mathrm{C}\left( \pm 1^{\circ} \mathrm{C}\right)$ inside each of the desiccators. Results of oven moisture tests confirmed accuracy of the moisture meter being used to monitor addition of moisture to the samples.

\section{Conversion of respired $\mathrm{CO}_{2}$ to $\mathrm{DML}$ estimate}

The start of a respiration test $\left(t_{0}\right)$ was designated as the time when the temperature in the desiccator reached $35 \pm 1^{\circ} \mathrm{C} . \mathrm{C}_{\mathrm{CO}_{2}}$ readings were corrected using the appropriate calibration equation and by subtracting the $\mathrm{C}_{\mathrm{CO}_{2}}$ at $t_{0}$. Using the ideal gas law, corrected $\mathrm{C}_{\mathrm{CO}_{2}}$ readings were converted to accumulated mass of respired $\mathrm{CO}_{2}$ inside the desiccator (eq. 2), which, after normalizing to the mass of dry matter of the mixed soybean sample $\left(m_{d m}\right)$, was subsequently converted to $D M L$ (eq. 3 ), according to the 
stoichiometric relationship between $\mathrm{CO}_{2}$ and glucose during respiration:

$$
\sum m_{\mathrm{CO}_{2}}=C_{\mathrm{CO}_{2}}\left(\frac{P V M_{\mathrm{CO}_{2}}}{R T}\right)
$$

Aerobic respiration: $\quad \mathrm{C}_{6} \mathrm{H}_{12} \mathrm{O}_{6}+6 \mathrm{O}_{2} \rightarrow 6 \mathrm{CO}_{2}+6 \mathrm{H}_{2} \mathrm{O}+38$ ATP

$$
\mathrm{DML}=\left(\frac{\sum m_{\mathrm{CO}_{2}}}{m_{d m}}\right)\left(\frac{1 \mathrm{~mol} \mathrm{C}_{6} \mathrm{H}_{12} \mathrm{O}_{6}}{6 \mathrm{~mol} \mathrm{CO}_{2}}\right)\left(\frac{M_{\mathrm{C}_{6} \mathrm{H}_{12} \mathrm{O}_{6}}}{M_{\mathrm{CO}_{2}}}\right)
$$

where $\sum m_{\mathrm{CO}_{2}}$ is the accumulated mass of respired $\mathrm{CO}_{2}(\mathrm{~g}), P$ is the pressure inside the desiccator $(1 \mathrm{~atm})$, $V$ is the desiccator volume $(10 \mathrm{~L}), R$ is the ideal gas constant $\left(0.08205 \mathrm{Latm} \mathrm{K}^{-1} \mathrm{~mol}^{-1}\right), T$ is the temperature $(\mathrm{K})$, and $M_{\mathrm{C}_{6} \mathrm{H}_{12} \mathrm{O}_{6}}$ and $M_{\mathrm{CO}_{2}}$ are the molar masses of glucose $\left(180.16 \mathrm{~g} \mathrm{~mol}^{-1}\right)$ and carbon dioxide $(44 \mathrm{~g}$ $\left.\mathrm{mol}^{-1}\right)$, respectively.

\section{Rate of dry matter loss}

Time series $D M L$ estimates showed an initial lag period and curvilinear shape until about 0.05\% DML was reached followed by a steady increase in $D M L$ at a constant rate (fig.4). The time at which $D M L$ reached $0.05 \%\left(t_{0.05}\right)$ was considered the start time of grain $D M L . v_{D M L}$ was estimated by taking the slope of the best-fit line from $t_{0.05}$ until the experiment end using the linear regression option of the Data Analysis ToolPak in MS Excel (Office 365, Microsoft Corporation, Redmond, WA, USA). DML rates for samples with splits were normalized by dividing the rate for a given percent splits, $v_{D M L, x_{s}}$ by $v_{D M L, x_{s}}=0$ to yield a ratio, $R_{x_{s}}$, which provided the relative rates of $D M L$. 


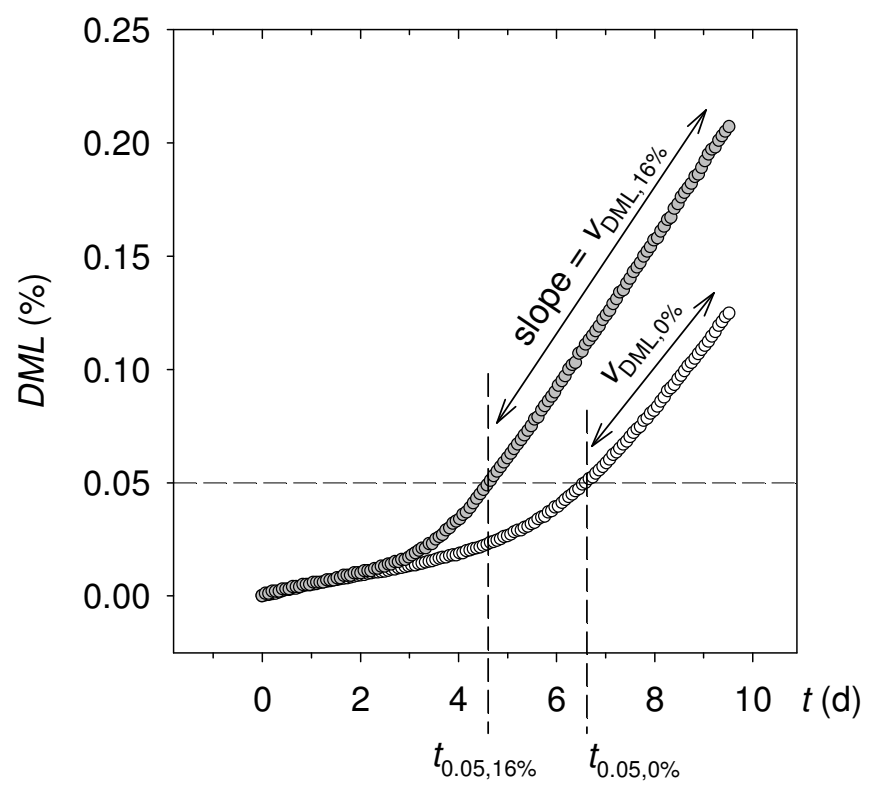

Figure 4. Rates of dry matter loss $\left(\mathrm{v}_{\mathrm{DML}, \mathrm{x}_{\mathrm{s}}}, \% \mathrm{~d}-1\right)$ were initially low and did not reach steady-state until after about $0.05 \% D M L$ was reached. Rate of $D M L$ was estimated as slope of the steady-state increase in $D M L$ after this time. The two curves show typical accumulated $D M L$ for a sample with $16 \%$ splits and another control with $0 \%$.

\section{Statistical Analyses}

\section{ANOVA with Tukey's range test}

One-way analysis of variance (ANOVA) tests were conducted using the PROC ANOVA function with Tukey's range test in SAS (2017 University Edition Software, SAS Institute, Inc., Cary, NC, USA). Response variables were $v_{D M L}$ with four treatment levels of $x_{s}(0,4,8$ and $16 \% \mathrm{w} / \mathrm{w})$, and $R_{x_{s}}$ with three treatment levels of $x_{s}(4,8$, and $16 \% \mathrm{w} / \mathrm{w})$. Differences among treatment means were assumed significant at $\alpha=0.05$. If treatment effects were significant, means were separated using the Tukey t-test option.

\section{Developing a splits multiplier $\left(M_{S}\right)$ based on $R_{x_{s}}$}

By definition, storage time is inversely proportional to $v_{D M L}$, so the safe storage time $t_{s}$ for soybean samples with a given $\%$ splits (i.e. $t_{s, x_{s}}$ ) is proportional to $t_{s}$ with $0 \%$ splits:

$$
\begin{gathered}
v_{D M L}=\frac{\Delta D M L}{\Delta t}=\frac{\Delta D M L}{t_{s}-0}=\frac{\Delta D M L}{t_{s}} \\
\frac{t_{s, x_{S}}}{t_{s, x_{s}=0}}=\frac{v_{D M L, x_{s}=0}}{v_{D M L, x_{S}}}
\end{gathered}
$$


Thus, the relation between $t_{s, x_{s}}$ and $\left.t_{s, x_{s}=0}\right)$ is:

$$
t_{s, x_{S}}=\left(\frac{v_{D M L, x_{s}=0}}{v_{D M L, x_{S}}}\right) t_{s, x_{s=0}}=\frac{1}{R_{x_{S}}} t_{s, x_{s=0}}=M_{S} t_{s, x_{S}=0}
$$

which suggests that $M_{S}$ for soybeans may be estimated as $1 / R_{x_{s}}$ (eq. 6). Note that soybeans used in the control and mixed samples were harvested from a single lot, so it was assumed that the degree of mechanical damage to the seed coat of the whole and split beans were the same and that the $M_{S}$ estimate incorporated effects from both mechanical damage and $x_{s}$. The relationship between $M_{S}$ and $x_{s}$ was fitted with linear and exponential equations (Sigmaplot Version 13, Systat Software, San Jose, CA, USA). Because the $M_{D}$ equation for shelled corn in the ASABE Standard D535 (R2019) is the only available reference giving values for a damage multiplier, the regression results and overall effect of split soybeans on $t_{s}$ from this paper were compared to the $\mathrm{M}_{\mathrm{D}}$ for corn. .

\section{RESULTS AND DISCUSSION}

\section{DRY MATTER LOSS ESTIMATES AND RATES}

$D M L$ estimates over time showed initial lag periods ranging from $2.82 \mathrm{~d}$ to $7.21 \mathrm{~d}$, decreasing as $x_{s}$ increased (fig. 5). This lag period was observed by Rukunudin et al. (2004) and Trevisan (2017) in their studies, where grain respiration was measured in systems with a steady supply of airflow to the grain mass. However, Ochandio et al. (2012) and Jian et al. (2014) used hermetically sealed systems, similar to the ones used in this study, and did not report an initial lag period, due to the extremely low $D M L$ values they observed.

Over a 10-day respiration test, $D M L$ reached $0.09 \%$ to $0.16 \%$ for control samples $\left(x_{s}=0 \%\right.$ splits). Maximum $D M L$ values increased with increasing $x_{s}$ : $0.10 \%$ to $0.21 \%$ for $4 \%$ splits, $0.14 \%$ to $0.27 \%$ for $8 \%$ splits, and $0.19 \%$ to $0.39 \%$ for $16 \%$ splits. After 2 to 4 days of storage, soybeans started to exhibit visible mold growth, which may explain the steady increase after $0.05 \%$ on $D M L$, as verified by 
inspection. At the end of the tests, visible mold growth increased within splits percentage.
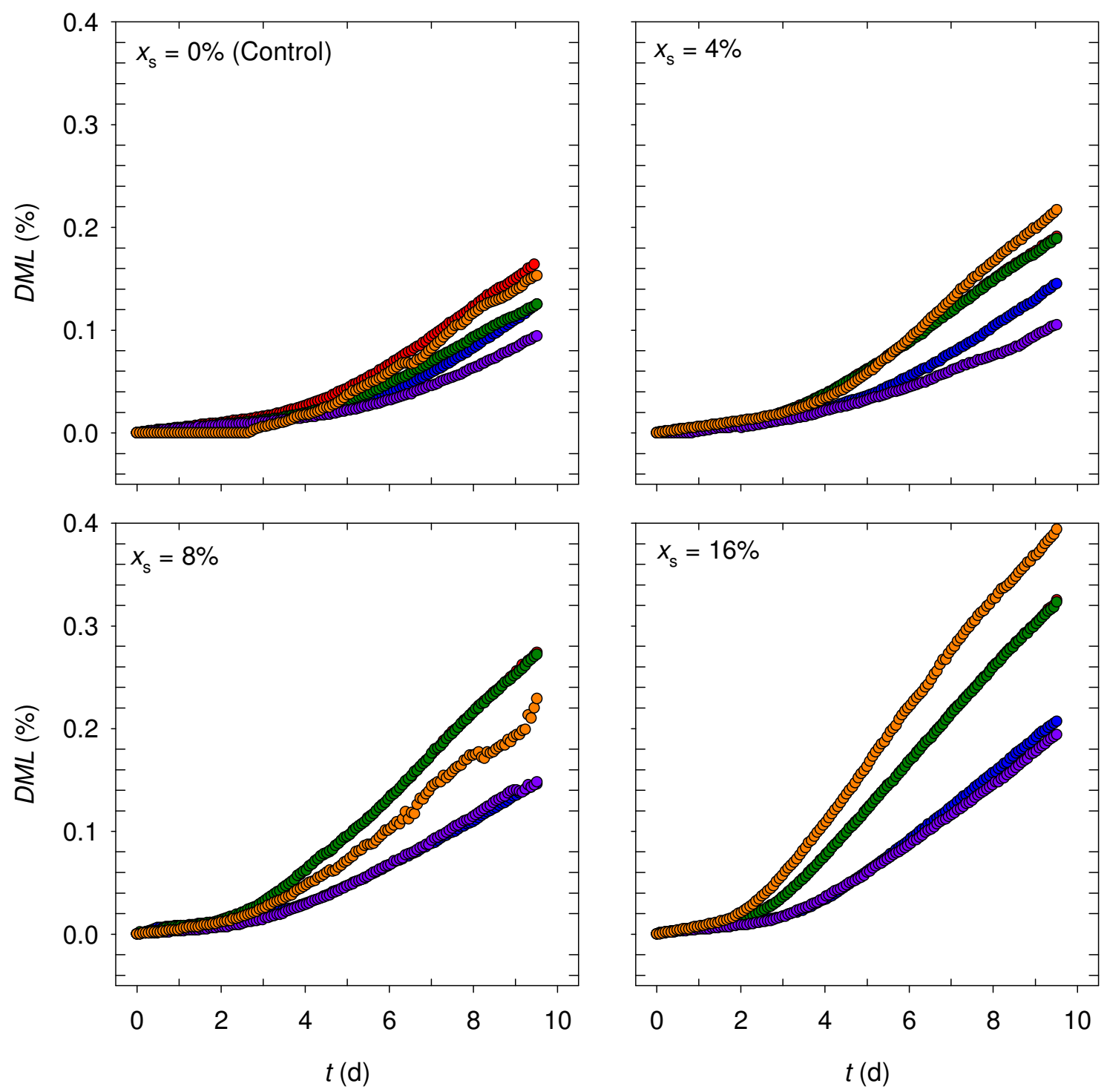

Figure 5. Dry matter loss increased with increasing splits content $\left(x_{s}, \%\right.$ w/w). Each plot shows data from five replications. One or more replicates cannot be distinguished because data overlapped.

Mean $v_{D M L}$ for samples with $16 \%$ split beans content was greater than that of control samples but was not different from those of samples with $8 \%$ splits (table 1). Likewise, mean $v_{D M L}$ for the control sample was not different from that of samples with $4 \%$ splits. Variance of the mean $v_{D M L}$ values increased with increasing $x_{s}$ and was large enough to result in overlapping treatment means. Similarly, the normalized $v_{D M L}$ comparison to that of the control showed a difference between $R_{x_{s}=4 \%}$ and $R_{x_{S}=16 \%}$, but neither values 
were different from $R_{x_{s}=8 \%}$ (table 2), owing to large standard deviations $\left(\sigma_{R}\right)$ at $8 \%$ and $16 \%$ splits content.

Table 1. Dry matter loss rates of soybeans at $18 \%$ moisture content with $0-16 \%$ (w/w) splits content, stored at $35^{\circ} \mathrm{C}$.

\begin{tabular}{|c|c|c|c|c|c|c|c|}
\hline \multirow[t]{2}{*}{$\mathrm{x}_{\mathrm{s}}(\% \mathrm{w} / \mathrm{w})$} & \multicolumn{5}{|c|}{$\mathrm{v}_{\mathrm{DML}}(\% \mathrm{~d}-1)^{[\mathrm{a}]}$} & \multirow{2}{*}{\multicolumn{2}{|c|}{ 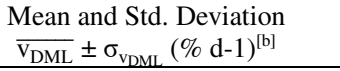 }} \\
\hline & Rep 1 & Rep 2 & Rep 3 & Rep 4 & Rep 5 & & \\
\hline 0 & 0.0245 & 0.0268 & 0.0222 & 0.0185 & 0.0266 & $0.0237 \pm 0.0035$ & b \\
\hline 4 & 0.0240 & 0.0282 & 0.0281 & 0.0168 & 0.0350 & $0.0264 \pm 0.0066$ & $\mathrm{~b}$ \\
\hline 8 & 0.0215 & 0.0376 & 0.0372 & 0.0227 & 0.0300 & $0.0298 \pm 0.0076$ & $a b$ \\
\hline 16 & 0.0318 & 0.0450 & 0.0448 & 0.0283 & 0.0528 & $0.0405 \pm 0.0101$ & $\mathrm{a}$ \\
\hline
\end{tabular}

${ }^{[a]}$ Standard errors of the rate estimates were less than $0.0001 \% \mathrm{~d}^{-1}$.

${ }^{[b]}$ Means followed by the same letter were not different from each other $(p<0.05)$.

Table 2. Normalized dry matter loss rates of soybeans $\left(\boldsymbol{R}_{x_{s}}\right)$ at $18 \%$ moisture content with $4-6 \%(\mathrm{w} / \mathrm{w})$ splits content, stored at $35^{\circ} \mathrm{C}$ and splits multipliers estimate $\left(M_{S}\right)$.

\begin{tabular}{|c|c|c|c|c|c|c|c|c|}
\hline \multirow{2}{*}{$\begin{array}{l}x_{s}(\% \\
\mathrm{w} / \mathrm{w})\end{array}$} & \multicolumn{5}{|c|}{$R_{x_{s}}=v_{D M L, x_{s}} / v_{D M L, x_{s}=0}$} & \multirow{2}{*}{\multicolumn{2}{|c|}{$\begin{array}{c}\text { Mean and Std. Deviation } \\
\qquad \overline{R_{x_{s}}} \pm \sigma_{R}{ }^{\text {al] }}\end{array}$}} & \multirow[t]{2}{*}{$M_{s}=1 / R_{x_{s}}$} \\
\hline & Rep 1 & Rep 2 & Rep 3 & Rep 4 & Rep 5 & & & \\
\hline 4 & 0.98 & 1.05 & 1.27 & 0.91 & 1.32 & $1.10 \pm 0.18$ & $\mathrm{~b}$ & 0.91 \\
\hline 8 & 0.88 & 1.40 & 1.68 & 1.23 & 1.13 & $1.26 \pm 0.30$ & $a b$ & 0.79 \\
\hline 16 & 1.30 & 1.68 & 2.02 & 1.53 & 1.98 & $1.70 \pm 0.31$ & $\mathrm{a}$ & 0.59 \\
\hline
\end{tabular}

${ }^{[a]}$ Means followed by the same letter were not different from each other $(p<0.05)$.

Per ASABE Standard D535 (R2019), $M_{D}$ for shelled corn ranges from 1.0 to 0.8 for mechanically harvested corn as the portion of damaged kernels increases from 30 to $40 \%$ (w/w). For soybeans, the mean $M_{S}$, estimated as the inverse of $R_{x_{s}}$ (eq. 6), ranged from 1.0 to 0.6 as $x_{s}$ increased from $0 \%$ to $16 \%$ (w/w) (fig. 6). While it appeared that $M_{S}$ for soybeans was more sensitive to damage than $M_{D}$ for corn kernels, it is important to note the difference in the definition of "damage" in this study compared to that used in the Standard. Here, the damage level was defined as $x_{s}$ in mixed soybean samples tested while the Standard uses the definition from Stroshine and Yang (1990), in which damage was percent by weight of kernels in a 100 g sample with pieces of kernel broken away or with cuts or abrasion to the pericarp as determined by visual inspection without staining or magnification. Nevertheless, based on these tests, the relationship between $M_{S}$ and $x_{S}$ for soybeans can be described using a linear or exponential model, with a lower standard error (SE) obtained with the linear model (fig. 6). 


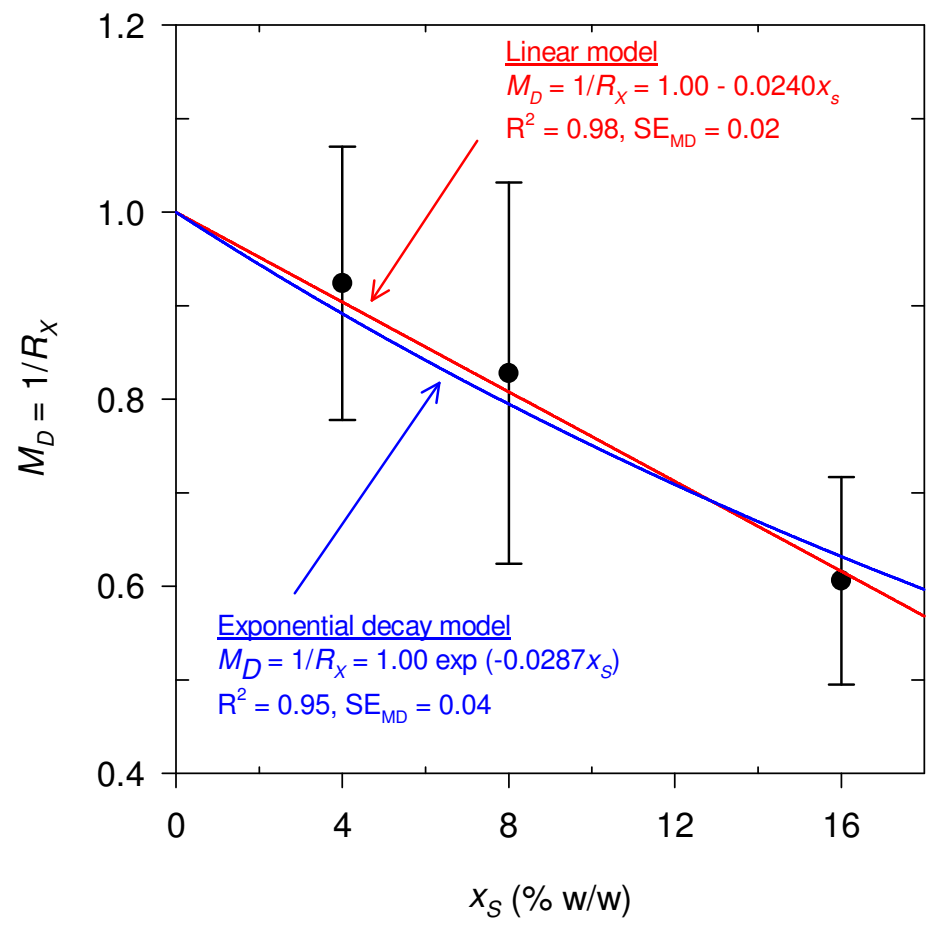

Figure 6. Linear and exponential models showing the relationship between damage multiplier $\left(M_{D}\right)$ for soybeans and splits content. The linear model yielded a lower standard error $(S E)$.

US Standard Grades for soybeans include other factors that indicate damage to seeds. These include seeds damaged on their germ or badly damaged by diseases, frost, or insect activity, along with seeds discolored by heating, or by contact with the ground or weather, or otherwise physically damaged. Factors from this list that have a significant effect on $D M L$ could be identified and appropriate multipliers could be determined for these factors. As mentioned in the introduction, lipid oxidation and protein degradation are also important quality attributes. Therefore, studies could also be conducted to determine whether there is a relationship between these two quality attributes and $D M L$.

\section{CONCLUSION}

The rate of $D M L$ of soybeans increased modestly with increasing splits content $\left(x_{s}\right)$, with a four-fold increase in split beans (from $4 \%$ to $16 \% \mathrm{w} / \mathrm{w}$ ) resulting in 1.5 times greater $v_{D M L}$. No significant difference in mean $v_{D M L}$ was detected between samples with $8 \%$ and $16 \%$ split beans. The same trend held true when 
$v_{D M L}$ were normalized to that of control samples to yield the ratio of dry matter loss at different percentages of splits $\left(R_{x_{s}}\right)$. The inverse relationship between $R_{x_{s}}$ and splits multiplier $\left(M_{S}\right)$ showed that the effect of increasing the percent by weight splits in soybeans from $0 \%$ to $16 \%$ was substantially greater than the change from $30 \%$ to $40 \%$ by weight damaged kernels for shelled corn. If all other factors are considered constant, it can be suggested that the presence of a high proportion of splits could substantially reduce the time required for the soybeans to reach $0.5 \% D M L$. This research was a useful step towards understanding the effects of split beans on safe storage time of $18 \%$ moisture content soybeans at $35^{\circ} \mathrm{C}$ under hermetic conditions and could be expanded in the future to cover a wider range of moisture contents and storage temperatures. More studies could also be conducted to include other damage factors on seeds and its relationship with lipid oxidation and protein degradation.

\section{ACKNOWLEDGEMENTS}

This work was supported in part by the ADM Institute for the Prevention of Postharvest Loss at the University of Illinois at Urbana-Champaign, Agência USP de Inovação at the University of São Paulo Brazil, and USDA Multi-State Project NC-213. The authors thank Tim Lecher for his technical assistance.

\section{REFERENCES}

Alencar, E. R., Faroni, L. R. D., Peternelli, L. A., da Silva, M. T. C., \& Costa, A. R. (2010). Influence of soybean storage conditions on crude oil quality. Revista Brasileira de Engenharia Agrícola e Ambiental, 14(3), 303-308. https://doi.org/10.1590/s1415-43662010000300010

ASABE Standards. (R2017). S352.2: Moisture Measurement — Unground Grain and Seeds. St. Joseph, MI: ASABE.

ASABE Standards. (R2019). D535: Shelled Corn Storage Time for 0.5\% Dry Matter Loss. St. Joseph, MI: ASABE. Bern, C. J., Rukunudin, I. H., Zagrabenyev, D. O., \& Cogdill, R. P. (1999). Deterioration of soybeans during storage. Proc. 7th Int. Working Conf. Stored Prod. Prot. 2, pp. 1632- 1641. Sichuan, China: Sichuan Publishing 
House of Science and Technology.

Carr, R. A. (1976). Degumming and refining practices in the U.S. J. Am. Oil Chem. Soc., 53(6), 347-352. https://doi.org/10.1007/bf02605721

Coker, R. D. (1994). The biodeterioration of grain and the risk of mycotoxins. In Grain storage techniques: evolution and trends in developing countries (109 ed., pp. 25-39). Rome, Italy: FAO Agricultural Services Bulletin.

Danao, M.-G. C., Zandonadi, R. S., \& Gates, R. S. (2015). Development of a grain monitoring probe to measure temperature, relative humidity, carbon dioxide levels and logistical information during handling and transportation of soybeans. Comput. Electron. Agric., 119, 74-82.

https://doi.org/10.1016/j.compag.2015.10.008

Fortes, M., \& Okos, M. R. (1980). Changes in physical properties of corn during drying. Trans. ASAE, 23(4), 10041008. https://doi.org/10.13031/2013.34705

Jian, F., Chelladurai, V., Jayas, D. S., Demianyk, C. J., \& White, N. D. G. (2014). Interstitial concentrations of carbon dioxide and oxygen in stored canola, soybean, and wheat seeds under various conditions. J. Stored Prod. Res., 57, 63-72. https://doi.org/10.1016/j.jspr.2013.12.002

Kong, F., \& Chang, S. K. C. (2013). Changes in protein characteristics during soybean storage under adverse conditions as related to tofu making. J. Agric. Food Chem., 61(2), 387-393. https://doi.org/10.1021/jf3032606

Mustakas, G. C., Albrecht, W. J., McGhee, J. E., Black, L. T., Bookwalter, G. N., \& Griffin, E. L. (1969). Lipoxidase deactivation to improve stability, odor and flavor of full-fat soy flours. J. Am. Oil Chem. Soc., 46(11), 623-626. https://doi.org/10.1007/bf02544982

Ochandio, D., Bartosik, R., Yommi, A., \& Cardoso, L. (2012). Carbon dioxide concentration in hermetic storage of soybean (glycine max) in small glass jars. Proc. 9th Int. Conf. Controlled Atmosphere and Fumigation in Stored Products. pp. 495-500. Turkey: ARBER Professional Congress Services.

Paulsen, M. R., Nave, W. R., Mounts, T. L., \& Gray, L. E. (1981). Storability of harvest-damaged soybeans. Trans. ASAE, 24(6), 1583-1589. https://doi.org/10.13031/2013.34494 
Pereira Da Silva, A. B. (2018). Dry matter loss rates of soybeans: Effects of respiration measurement system, damage by splits, and moisture content at elevated temperatures. MS thesis. Urbana, IL, USA: University of Illinois at Urbana-Champaign, Department of Agricultural and Biological Engineering.

Rausch, K. D., Pruiett, L. E., Wang, P., Xu, L., Belyea, R. L., \& Tumbleson, M. E. (2009). Laboratory measurement of yield and composition of dry-milled corn fractions using a shortened, single-stage tempering procedure. Cereal Chem., 86(4), 434-438. https://doi.org/10.1094/cchem-86-4-0434

Rukunudin, I. H., Bern, C. J., Misra, M. K., \& Bailey, T. B. (2004). Carbon dioxide evolution from fresh and preserved soybeans. Trans. ASAE, 47(3), 827-833. https://doi.org/10.13031/2013.16079

Somavat, P., Li, Q., Kumar, D., de Mejia, E. G., Liu, W., Rausch, K. D., . . Singh, V. (2017). A new lab scale corn dry milling protocol generating commercial sized flaking grits for quick estimation of coproduct yield and composition. Industrial Crops and Products, 109, 92-100.

Steele, J. L. (1967). Deterioration of damaged shelled corn as measured by carbon dioxide production. PhD diss. Ames, IA, USA: Iowa State University, Department of Agricultural Engineering.

Stroshine, R. L., \& Yang, X. (1990). Effects of hybrid and grain damage on estimated dry matter loss for highmoisture shelled corn. Trans. ASAE, 33(4), 1291-1298. https://doi.org/10.13031/2013.31471

Trevisan, L. R. (2017). Evaluating dry matter loss rates of 14 to $22 \%$ moisture content soybeans at $35^{\circ} \mathrm{C}$ using a dynamic grain respiration measurement system. MS thesis. Urbana, IL, USA: University of Illinois at UrbanaChampaign, Department of Agricultural and Biological Engineering.

\section{NOMENCLATURE}

\begin{tabular}{cll}
\hline Abbreviation & Definition & \\
\hline ANOVA & Analysis of variance \\
FFA & Free fatty acids \\
w.b. & Wet-basis & \\
& & \\
\hline Symbol & Chemical name & \\
\hline $\mathrm{ATP}$ & Adenosine triphosphate & \\
$\mathrm{CO}_{2}$ & Carbon dioxide & Unit of measurement \\
$\mathrm{C}_{6} \mathrm{H}_{12} \mathrm{O}_{6}$ & Glucose & Water \\
$\mathrm{H}_{2} \mathrm{O}$ & Oxygen & \\
$\mathrm{O}_{2}$ & & Description \\
\hline Variable & Change or difference &
\end{tabular}




\begin{tabular}{|c|c|c|}
\hline Variable & Description & Unit of measurement \\
\hline$\phi$ & Relative humidity & $\% \mathrm{RH}$ \\
\hline$\sigma_{R}$ & Standard deviation of the ratio & --- \\
\hline$\sigma_{v_{D M L}}$ & Standard deviation of the rate of dry matter loss & $\% \mathrm{~d}^{-1}$ \\
\hline $\mathrm{C}_{\mathrm{CO}_{2}}$ & Concentration of carbon dioxide & $\%$ \\
\hline$D$ & Damaged kernels & $\% \mathrm{w} / \mathrm{w}$ \\
\hline$D M L$ & Dry matter loss & $\% \mathrm{w} / \mathrm{w}$ \\
\hline$m_{d m}$ & Dry matter mass & $\mathrm{g}$ \\
\hline $\mathrm{M}_{\mathrm{CO}_{2}}$ & Molar mass of carbon dioxide & $\mathrm{g} \mathrm{mol}^{-1}$ \\
\hline$M_{\mathrm{C}_{6} \mathrm{H}_{12} \mathrm{O}_{6}}$ & Molar mass of glucose & $\mathrm{g} \mathrm{mol}^{-1}$ \\
\hline$M_{D}$ & Multiplier, damage & --- \\
\hline$M_{F}$ & Multiplier, fungicide treatment & --- \\
\hline$M_{H}$ & Multiplier, hybrid resistance & --- \\
\hline$M_{T}$ & Multiplier, temperature & --- \\
\hline$M_{w}$ & Multiplier, moisture & --- \\
\hline$\sum m_{\mathrm{CO}_{2}}$ & Mass of accumulated mass of respired carbon dioxide & $\mathrm{g}$ \\
\hline$p$ & Probability value & --- \\
\hline$P$ & Pressure inside the desiccator & atm \\
\hline$R$ & Ideal gas constant & $\mathrm{L}$ atm $\mathrm{K}^{-1} \mathrm{~mol}^{-1}$ \\
\hline$R_{x_{s}}$ & $\begin{array}{l}\text { Ratio of dry matter loss rate at a specific splits content } \\
\text { to that of the control (or zero splits content) }\end{array}$ & --- \\
\hline SE & Standard error of the damage multiplier & --- \\
\hline$T$ & Temperature & ${ }^{\circ} \mathrm{C}$ \\
\hline$t_{0}$ & Onset of grain storage (i.e., "time zero") & $\mathrm{d}$ \\
\hline
\end{tabular}

Author 1

\begin{tabular}{|c|c|c|c|c|c|c|}
\hline $\begin{array}{c}\text { First name } \\
\text { or initial }\end{array}$ & $\begin{array}{c}\text { Middle } \\
\text { name or } \\
\text { initial }\end{array}$ & Surname & $\begin{array}{c}\text { Suffix } \\
\text { (Jr., III, } \\
\text { etc.) }\end{array}$ & $\begin{array}{c}\text { Role } \\
\text { (job title, etc.) }\end{array}$ & $\begin{array}{c}\text { Email (and phone for } \\
\text { contact author) }\end{array}$ & $\begin{array}{c}\text { Contact } \\
\text { author? } \\
\text { yes or no }\end{array}$ \\
\hline Ana & B & Gatsakos & & $\begin{array}{c}\text { Graduate Student, } \\
\text { ASABE member }\end{array}$ & abp3@illinois.edu & No \\
\hline
\end{tabular}

Affiliation for Author1

\begin{tabular}{|c|c|c|c|}
\hline Organization & Address & Country & URL or other info. \\
\hline $\begin{array}{c}\text { University of Illinois at } \\
\text { Urbana-Champaign }\end{array}$ & $\begin{array}{c}\text { 1304 W. Pennsylvania Ave. } \\
\text { Urbana, IL 61801 }\end{array}$ & USA & \\
\hline
\end{tabular}

Author 2

\begin{tabular}{|c|c|c|c|c|c|c|}
\hline $\begin{array}{c}\text { First name } \\
\text { or initial }\end{array}$ & $\begin{array}{c}\text { Middle } \\
\text { name or } \\
\text { initial }\end{array}$ & Surname & $\begin{array}{c}\text { Suffix } \\
\text { (Jr., III, } \\
\text { etc.) }\end{array}$ & $\begin{array}{c}\text { Role } \\
\text { (job title, etc.) }\end{array}$ & $\begin{array}{c}\text { Email (and phone for } \\
\text { contact author) }\end{array}$ & $\begin{array}{c}\text { Contact } \\
\text { author? } \\
\text { yes or no }\end{array}$ \\
\hline Thomas & B & Scatolini & & $\begin{array}{c}\text { Undergraduate } \\
\text { student }\end{array}$ & $\frac{\text { thomas.scatolini@ us }}{\text { p.br }}$ & No \\
\hline
\end{tabular}

Affiliation for Author 2

\begin{tabular}{|c|c|c|c|}
\hline Organization & Address & Country & URL or other info. \\
\hline University of São Paulo & 225 Duque de Caxias Norte & Brazil & \\
& Campus Fernando Costa & & \\
& Pirassununga, SP 13635-900 & & \\
\hline
\end{tabular}

Author 3 (repeat Author and Affiliation tables for each author)

\begin{tabular}{|c|c|c|c|c|c|c|}
\hline $\begin{array}{c}\text { First name } \\
\text { or initial }\end{array}$ & $\begin{array}{c}\text { Middle } \\
\text { name or } \\
\text { initial }\end{array}$ & Surname & $\begin{array}{c}\text { Suffix } \\
\text { (Jr., III, } \\
\text { etc.) }\end{array}$ & $\begin{array}{c}\text { Role } \\
\text { (job title, etc.) }\end{array}$ & $\begin{array}{c}\text { Email (and phone for } \\
\text { contact author) }\end{array}$ & $\begin{array}{c}\text { Contact } \\
\text { author? } \\
\text { yes or no }\end{array}$ \\
\hline
\end{tabular}




\begin{tabular}{|c|c|c|c|c|c|}
\hline Mary-Grace & C. & Danao & & $\begin{array}{r}\text { Research } \\
\text { Associate } \\
\text { Professor, } \\
\text { ASABE Member }\end{array}$ & \\
& & & & Nonao2@unl.edu \\
\hline
\end{tabular}

\section{Affiliation for Author 3}

\begin{tabular}{|c|c|c|c|}
\hline Organization & Address & Country & URL or other info. \\
\hline $\begin{array}{c}\text { University of Nebraska- } \\
\text { Lincoln }\end{array}$ & $\begin{array}{c}1901 \text { N. 21st St. } \\
\text { Lincoln, NE 68588-6205 }\end{array}$ & USA & \\
\hline
\end{tabular}

Author 4 (repeat Author and Affiliation tables for each author)

\begin{tabular}{|c|c|c|c|c|c|}
\hline $\begin{array}{c}\text { First name } \\
\text { or initial }\end{array}$ & $\begin{array}{c}\text { Middle } \\
\text { name or } \\
\text { initial }\end{array}$ & Surname & $\begin{array}{c}\text { Suffix } \\
\text { (Jr., III, } \\
\text { etc.) }\end{array}$ & $\begin{array}{c}\text { Role } \\
\text { (job title, etc.) }\end{array}$ & $\begin{array}{c}\text { Email (and phone for } \\
\text { contact author) }\end{array}$ \\
\hline Richard & S. & Gates & $\begin{array}{c}\text { Professor, } \\
\text { Director, } \\
\text { ASABE Fellow }\end{array}$ & rsgates@iastate.edu \\
\hline
\end{tabular}

Affiliation for Author 4

\begin{tabular}{|c|c|c|c|}
\hline Organization & Address & Country & URL or other info. \\
\hline Iowa State University & 1029 N. University Blvd. & USA & \\
& Ames, IA 50011-4660 & & \\
\hline
\end{tabular}

Author 5 (repeat Author and Affiliation tables for each author)

\begin{tabular}{|c|c|c|c|c|c|c|}
\hline $\begin{array}{l}\text { First name } \\
\text { or initial }\end{array}$ & $\begin{array}{l}\text { Middle } \\
\text { name or } \\
\text { initial }\end{array}$ & Surname & $\begin{array}{c}\text { Suffix } \\
\text { (Jr., III, } \\
\text { etc.) }\end{array}$ & $\begin{array}{c}\text { Role } \\
\text { (job title, etc.) }\end{array}$ & $\begin{array}{l}\text { Email (and phone for } \\
\text { contact author) }\end{array}$ & $\begin{array}{c}\text { Contact } \\
\text { author? } \\
\text { yes or no }\end{array}$ \\
\hline
\end{tabular}

Affiliation for Author 5

\begin{tabular}{|c|c|c|c|}
\hline Organization & Address & Country & URL or other info. \\
\hline $\begin{array}{c}\text { University of Illinois at } \\
\text { Urbana-Champaign }\end{array}$ & $\begin{array}{c}\text { 1304 W. Pennsylvania Ave. } \\
\text { Urbana, IL 61801 }\end{array}$ & USA & \\
\hline
\end{tabular}

